\title{
Hubungan Antara Kecerdasan Emosi dengan Agresivitas pada Atlet Futsal
}

\author{
Faris Zaky Rinanda ${ }^{1} \mathcal{E}$ Haryanta $^{2}$ \\ Fakultas Psikologi Universitas Gadjah Mada
}

\begin{abstract}
One of the factors that contribute to the athlete's perfomance is his emotional state. Athletes who are emotionally unstable tend to be more easily expressed aggression in front of opponents. This research aims to investigate the relationship between emotional intellegence and aggressiveness among futsal athlete. It was hypothesized that there a negative relationship between emotional intelligence and aggressiveness. There were 111 futsal athletes of University $X$ from many faculties in this research. Data analysis using Product Moment correlation technique from Pearson showed $r x y=-0.488$ with $\mathrm{p}<0,01$ pointing out that there is significant negative correlation between emotional intelligence and aggressiveness among futsal athlete. That result proved that hypothesis was accepted.
\end{abstract}

Keywords : aggressiveness; emotional intellegence; futsal athlete

\begin{abstract}
Abstrak. Salah satu faktor yang ikut berpengaruh terhadap performa atlet adalah kondisi emosinya. Atlet yang emosinya tidak stabil cenderung lebih mudah mengeluarkan sikap agresi di depan lawan. Penelitian ini bertujuan untuk mengetahui hubungan antara kecerdasan emosi dengan agresivitas pada atlet futsal. Hipotesis dalam penelitian ini adalah terdapat hubungan negatif antara kecerdasan emosi dengan agresivitas pada atlet futsal. Subjek dalam penelitian ini berjumlah 111 atlet futsal Universitas $X$ yang berasal dari beberapa fakultas. Analisis data pada penelitian ini menggunakan teknik korelasi Product Moment dari Pearson menghasilkan $\mathrm{rxy}=-0.488$ dengan $\mathrm{p}<0,01 \mathrm{yang}$ menunjukkan adanya hubungan negatif yang signifikan antara kecerdasan emosi dan agresivitas atlet. Kesimpulan penelitian ini menunjukkan bahwa semakin tinggi kecerdasan emosi yang dimiliki seorang atlet futsal, maka semakin rendah agresivitas seorang atlet futsal saat bertanding.
\end{abstract}

Kata Kunci : agresivitas atlet; atlet futsal; kecerdasan emosi

Agresivitas merupakan salah satu bentuk perilaku yang dimiliki oleh manusia terlebih pada seorang atlet. Agresi merupakan tingkah laku yang diarahkan dengan bertujuan menyakiti makhluk hidup lain yang ingin menghindari perlakuan semacam itu (Baron dan Byrne,

${ }^{1}$ Korespondensi mengenai isi artikel ini dapat dilakukan melalui: faris.zaky.r@mail.ugm.ac.id ,

${ }^{2}$ atau melalui hary psiko@ugm.ac.id

E-JURNAL GAMA JOP
2005). Agresi sendiri merupakan implikasi dari tindakan individu dengan emosi yang tidak terkontrol. Adapun agresi dapat berupa verbal maupun non verbal dan dapat terjadi akibat rangsangan internal maupun eksternal. Agresi merupakan salah satu bentuk dari emosi negatif, di mana ketika individu tersebut tidak mampu mengontrol emosinya maka yang terjadi adalah emosi negatif berupa perilaku agresi. Kematangan dalam 
mengontrol dan mengatur emosi inilah diperlukan guna mencegah perilaku agresi terjadi. Agresivitas yang dilakukan individu itu sendiri merupakan dampak dari stimulus yang diberikan lingkungan sekitar lalu direspon. Respon inilah yang terkadang salah dikarenakan seseorang individu tidak mampu mengatur dan mengelola emosinya, yang dapat mengakibatkan munculnya perilaku agresi. Dari hal ini terlihat bahwa kecerdasan emosi berhubungan dengan agresivitas pada seseorang individu.

Seseorang individu yang memasuki tahap remaja awal sampai akhir akan mengalami pencarian jati diri atau identitas diri. Dalam tahap tersebut individu juga membutuhkan yang dinamakan eksistensi, salah satu yang digemari oleh remaja adalah olahraga. Olahraga menjadi salah satu bidang yang diminati oleh para pelajar baik siswa maupun mahasiswa dan ada banyak jenisnya seperti, sepakbola, basket futsal, tenis meja, dan voli. Jika dilihat kembali menurut perkembangan bahwa masa remaja mempunyai emosi yang meluapluap, begitupun di bidang olahraga. Agresivitas yang tinggi menjadi hal yang umum terjadi di dalam dunia olahraga Indonesia khususnya pelajar. Lihat beberapa contoh dalam dunia olahraga, yang paling sering terjadi perkelahian antar pemain adalah sepakbola, basket, dan futsal. Sepakbola sendiri mempunyai pertandingan derby yang panas yang berpotensi memiliki agresivitas yang tinggi, sedangkan yang paling baru sendiri terdapat pada PON 2016 di mana cabang futsal terjadi kericuhan antar permain sehingga salah satu pemain Maluku Utara harus mengalami 22 jahitan. Kasus lain terjadi di Yogyakarta, di mana pertandingan futsal SMA berakhir dengan tragedi kericuhan. Dampak yang terjadi adalah menurunnya prestasi baik individu maupun tim yang dikarenakan agresivitas yang tinggi dan tidak terkontrol saat bertanding. Dapat terlihat bahwa agresivitas sebagai salah satu faktor yang merusak atau berpengaruh negatif kepada prestasi baik individu maupun tim. Selain itu peneliti juga melihat langsung saat kegiatan pekan olah raga di mana ada salah satu atlet futsal fakultas $\mathrm{X}$ tidak bisa menahan agresivitasnya dan mengakibatkan dia tidak bisa bertanding di pertandingan selanjutnya. Wawancara dilakukan peneliti untuk mengetahui sebab terjadinya atlet tersebut tidak mampu menahan agresivitasnya, atlet tersebut berinisial $\mathrm{C}$.

"Aku gak bisa mikir waktu itu Lae. Soalnya di dalam lapangan lawan main kasar ditambah suporter sana teriakteriak terus, yaudah aku gak bisa mikir tiba-tiba keluar aja gitu hehe. Ya dari SMA sih Zak, kan tau kau pasti tau SMA di Siantar kayak gimana, itu aja Porsenigama kemarin udah kucoba tahan-tahan Zak tetep aja gak bisa. Padahal turnamen-turnamen sebelumnya gak pernah aku gini Zak."

Terdapat faktor-faktor yang secara umum memengaruhi agresivitas seseorang, yaitu sosial, pribadi, dan situasional. Faktor sosial merupakan lingkungan yang membentuknya ikut berpengaruh, sedangkan pribadi adalah dari dalam diri sendiri, yang terakhir situasional yakni kejadian yang terjadi saat pertandingan sedang berlangsung, misalnya disebabkan efek dari kinerja buruk wasit maupun provokasi langsung dari pemain atau supporter lawan. Agresivitas yang dilakukan oleh remaja tidak lepas dari pengaruh lingkungan keluarga, utamanya orang tua. Orang tua yang tidak memberikan penguatan atau pengetahuan tentang cara mengendalikan 
emosi atau justru malah memberikan contoh sebagai role model yang negatif maka akan membuat anaknya kesulitan untuk mengontrol emosinya,

Kecerdasan emosi adalah salah satu faktor yang berhubungan dengan agresivitas maka individu-individu seharusnya belajar guna mengontrol emosi mereka seiring perkembangan dari tahap remaja akhir ke dewasa awal. Dijelaskan bahwa mekanisme utama yang menentukan agresivitas manusia yaitu proses belajar di masa lalu, penguatan dan imitasi, ketiga hal ini sangat menarik untuk diteliti berkaitan dengan besarnya dampak agresivitas pada anak usia sekolah dan remaja awal (Sears, Freedman, dan Peplau, 1994). Tahapantahapan sebelumnya hingga dewasa awal terjadi banyak dinamika dalam perilaku agresi, penguatan dan belajar sosial membuat kematangan emosi seseorang guna mengendalikan agresivitasnya.

Emosi merupakan akumulasi dari perasaan. Emosi digambarkan seperti setiap kegiatan atau pergolakan pikiran, nafsu, serta setiap keadaan mental yang hebat dan meluap luap. Emosi juga dapat didefinisikan ke dalam beberapa bentuk seperti amarah, takut, sedih, cinta, malu, terkejut dan jengkel.

Kecerdasan emosi amatlah penting dimiliki oleh setiap individu. Sejak kecil lingkungan keluarga berperan penting dalam membentuk kecerdasan emosi seorang individu, utamanya adalah orang tua. Orang tua diharapkan mampu melatih anaknya belajar menerapkan emosi dalam kehidupannya dengan tepat dan diajarkan pula mengendalikan serta pematangan emosi sejak dini agar tidak berakibat fatal nantinya. Dalam tahap perkembangannya juga seperti itu, meskipun dunia atau lingkungan seorang individu menjadi semakin luas peranan orang tua dalam membentuk kecerdasan emosi seorang individu amatlah penting. Ketika seorang individu merantau guna kuliah dan lepas dari orang tuanya disitulah kematangan emosi seseorang akan diuji apakah sudah matang dalam tahap-tahap pembentukan sebelumnya, atau malah sebaliknya. Kecerdasan emosi yang matang menjadikan seorang individu tersebut mampu mengendalikan diri sendiri serta memiliki daya tahan ketika menghadapi rintangan. Selain itu individu akan mampu mengendalikan impuls dan tidak cepat merasa puas, mampu mengatur suasana hati, dan mampu mengelola kecemasan agar tidak mengganggu kemampuan berpikir. Selain itu, individu juga mampu membina hubungan baik dengan orang lain, mudah mengendalikan emosi pada orang lain, dan penuh perhatian. Menurut Mayer, Caruso, dan Salovey (2016) orang yang mempunyai kecerdasan emosi yang baik berbeda dengan yang kurang baik, orang yang memiliki kecerdasan emosi yang baik mempunyai hubungan interpersonal yang baik setiap hari dalam hidupnya, terutama dalam lingkungan kerja maupun organisasi atau tim.

Kecerdasan emosi sebagai sebuah kemampuan untuk memotivasi diri sendiri dan menghadapi frustasi, mengendalikan dorongan hati dan tidak senang secara berlebihan. Menjaga suasana hati dan menjaga agar beban tidak terlalu berat yang menyebabkan stres. Agresi sendiri merupakan salah satu bentuk respon dari frustasi. Hal tersebut menunjukan adanya pengaruh kecerdasan emosi terhadap perilaku agresi yang seringkali menjadi suatu kebiasaan. Individu yang sering melakukan perkelahian atau menunjukkan agresivitasnya merupakan individu yang tidak dapat mengendalikan dirinya. Remaja 
yang memiliki ambang marah rendah akan cenderung melakukan perilaku agresi lebih besar dibanding remaja yang mampu mengendalikan emosinya. Ketika ambang marah rendah maka tindakan emosional cenderung dilakukan, hal ini berkaitan dengan ketidakstabilan emosi yang dimiliki individu tersebut. Semua hal yang dihadapinya akan cenderung dihadapi dengan mengedepankan emosi. Hal ini bisa berakibat fatal bila dibiarkan terus menerus karena akan menjadi kebiasaan buruk yang dapat memengaruhi pola pikir individu tersebut. Kecerdasan emosi mempunyai peranan yang amat penting untuk mengendalikan agresivitas yang terkadang sudah menjadi sebuah kebiasaan pada seorang individu. Hal ini dibutuhkan karena seorang individu yang mempunyai kecerdasan emosi yang matang akan belajar mengelola emosi individu tersebut agar terhindar dari perilaku agresi. Menurut Baron dan Byrne (2005) provokasi langsung adalah pemicu yang kuat dari agresi. Jika seseorang individu mampu mengendalikan emosinya meskipun terdapat provokasi dari eksternal maka individu tersebut mampu mengendalikan agar tidak muncul perilaku agresi. Terlihat dalam turnamen (Pekan Olah Raga dan Seni Universitas X) 3-4 tahun terakhir provokasi dari pihak eksternal sangatlah kental dalam menyulut agresivitas seorang atlet, seperti supporter lawan, permainan kasar lawan, dan kesalahan wasit membuat seorang atlet fustal tersulut untuk melakukan tindakan agresi. Kecerdasan emosi yang memiliki peranan penting dalam mengendalikan agresivitas pada atlet futsal ini kadang tampak kadang tidak, padahal seharusnya pada usia mahasiswa seorang individu memasuki tahap perkembangan remaja akhir maupun dewasa awal yang secara perkembangan sudah mampu mematangkan emosi individu tersebut.

Kecerdasan emosi yang memiliki peranan penting dalam mengendalikan agresivitas dikarenakan individu yang memiliki kecerdasan emosi yang matang akan belajar untuk mengenali emosi, mengelola emosi, membina hubungan baik, berempati, oleh karena itu diharapkan dengan memiliki kecerdasan emosi seorang individu dapat mengontrol emosinya sehingga mampu menghindari perilaku agresi.

\section{Metode}

Metode pengumpulan data yang digunakan dalam penelitian ini menggunakan metode kuantitatif untuk menemukan hubungan antar variabel yang diteliti yaitu skala psikologi. Subjek dalam penelitian ini adalah mahasiswa laki-laki dan perempuan yang pernah mengikuti minimal satu pertandingan futsal di lingkup fakultas maupun universitas.

\section{Skala Kecerdasan Emosi}

Skala kecerdasan emosi yang digunakan dalam penelitian ini disusun oleh peneliti yang mencakup beberapa aspek kecerdasan emosi berdasarkan Goleman (1997), diantaranya mengenali emosi diri, mengelola emosi, memotivasi diri, mengenali emosi orang lain, dan membina hubungan sosial. Skala Kecerdasan emosi untuk uji coba berjumlah 25 aitem. Setelah melakukan uji daya beda aitem melalui teknik korelasi aitem total, ditemukan bahwa indeks daya beda yang dimiliki oleh skala kecerdasan emosi berkisar antara 0,139 sampai 0,737. Terdapat 3 aitem gugur dari 25 aitem skala kecerdasan emosi sehingga terdapat 22 aitem yang dinyatakan lolos. Setelah 
dilakukan pengguguran aitem, indeks daya beda yang dimiliki oleh skala kecerdasan emosi berkisar antara 0,280 sampai 0,744 dengan reliabilitas sebesar 0,876 .

\section{Skala Agresivitas}

Skala agresivitas yang digunakan dalam penelitian ini disusun oleh peneliti yang mencakup beberapa aspek agresivitas berdasarkan Buss dan Perry (1992), diantaranya agresi fisik, agresi verbal, kemarahan, dan permusuhan. Skala Agresivitas untuk uji coba berjumlah 29 aitem. Setelah dilakukan uji daya beda aitem melalui teknik korelasi aitem total ditemukan bahwa indeks daya beda berkisar antara 0,078 sampai 0,678. Terdapat 4 aitem gugur dari 29 aitem Skala Agresivitas sehingga terdapat 25 aitem yang dinyatakan lolos. Setelah dilakukan pengguguran aitem, Skala Agresivitas ini memiliki indeks daya beda berkisar antara 0,210 sampai 0,670 dengan reliabilitas 0,882 .

Jumlah subjek pada penelitian ini berjumlah 111 orang. Proses pengambilan data dilakukan dengan membagikan skala penelitian di Universitas $X$.

Penelitian ini menggunakan analisis data kuantitatif dengan metode statistik. Pengujian hipotesis ini menggunakan teknik analisis korelasi Product Moment Pearson. Penggunaan teknik korelasi tersebut karena kedua variabel dalam penelitian ini berbentuk skor interval. Uji normalitas sebaran dan uji linearitas hubungan harus dilakukan terlebih dahulu sebelum melakukan uji hipotesis. Saat kedua syarat tersebut terpenuhi, uji hipotesis bisa dilakukan. Keseluruhan pengolahan data penelitian ini menggunakan software SPSS (Statistical Program for Social Science).

\section{Hasil}

Berdasarkan uji asumsi yang sudah dilakukan, data yang digunakan dalam penelitian ini normal dan linier. Variabel kecerdasan emosi memperoleh nilai K-S Z 1,299 dengan signifikansi 0,069 ( $p>0,05)$ pada uji normalitas yang telah dilakukan. Kemudian variabel agresivitas atlet memperoleh skor K-S Z 1,354 dengan signifikansi $0,051(p>0,05)$. Hasil tersebut menunjukkan bahwa data dalam penelitian ini normal. Selanjutnya, berdasarkan pengolahan data melalui SPSS, didapatkan nilai $\mathrm{F}$ pada linearity sebesar 37,877 dengan nilai signifikansi sebesar $p=0.000(p<0.05)$ dan nilai $F$ pada deviation from linearity sebesar 1,293 dengan $p=0,172(p>0.05)$. Hasil tersebut menunjukkan bahwa data dalam penelitian ini linear. Berdasarkan hasil uji korelasi product moment diperoleh $\mathrm{r}=$ 0.488 dan $p<0.01$. Hasil negatif menunjukkan bahwa semakin tinggi kecerdasan emosi yang dimiliki seorang atlet maka semakin rendah tingkat agresivitas pada atlet tersebut, sehingga bisa dinyatakan bahwa hipotesis diterima.

\section{Diskusi}

Penelitian ini mempunyai tujuan untuk mengetahui hubungan antara kecerdasan emosi dengan agresivitas pada atlet futsal. Hasil analisis data menunjukkan bahwa terdapat hubungan yang signifikan antara kecerdasan emosi dengan agresivitas pada atlet futsal yang ditunjukkan dengan skor korelasi kedua variabel (rxy) sebesar -0.488 dengan taraf signifikansi 0.001. Hal tersebut menunjukkan bahwa korelasi antara variabel kecerdasan emosi dengan agresivitas bersifat negatif, yang dimaksud mempunyai korelasi bersifat negatif adalah semakin tinggi kecerdasan emosi 
seseorang atlet futsal maka akan semakin rendah agresivitas pada atlet futsal, begitu juga sebaliknya. Hasil analisis data tersebut sejalan dengan hipotesis penelitian ini yang menyatakan bahwa terdapat hubungan negatif kecerdasan emosi dengan agresivitas. Oleh karena itu hipotesis yang diajukan dalam penelitian ini dapat diterima.

Agresivitas yang dilakukan seseorang merupakan hasil dari sebuah pengambilan keputusan dari sebuah kejadian. Goleman (1997) mengatakan bahwa kecerdasan emosi berperan besar dalam pengambilan keputusan rasional terhadap suatu kejadian. Goleman juga menyatakan bahwa manusia memiliki dua pikiran. Pertama, pikiran rasional yang merupakan model pemahaman yang disadari, bijaksana, dan mampu bertindak hati-hati, sedangkan pikiran lainnya adalah impulsif, berpengaruh besar, dan terkadang tidak logis, pikiran tersebut adalah pikiran emosional. Dengan demikian dapat disimpulkan bahwa agresivitas dipengaruhi oleh pikiran emosional yang bisa dikendalikan oleh orang yang memiliki kecerdasan emosi yang tinggi, karena pikiran rasional dan bijaksana akan lebih dikedepankan oleh orang yang memiliki kecerdasan emosi yang tinggi.

Gardner (2006) menyatakan bahwa yang termasuk kecerdasan emosi seseorang adalah kecakapan mengenai perasaan kita sendiri yang terdiri dari kesadaran diri dan emosi. Kecerdasan emosi yang baik mampu membuat seseorang cakap tentang perasaan dirinya sendiri, jadi orang tersebut mampu mengatur atau menahan ketika mengetahui dirinya sedang dalam keadaan emosi dan tidak stabil karena jika diluapkan akan merugikan diri sendiri maupun lingkungan sekitar.
Menurut penelitian Das dan Tripathy (2015) membuktikan bahwa kecerdasan emosi mempunyai korelasi yang negatif dengan agresivitas, semakin baik kecerdasan emosi seseorang maka orang tersebut lebih mengikuti norma yang ada dan mampu mengendalikan agresivitasnya. Penelitian tersebut juga menemukan bahwa laki laki mempunyai kecenderungan agresivitas yang lebih tinggi bila dibandingkan dengan perempuan.

Agresivitas sebenarnya dapat diturunkan, jika seseorang mempunyai atau melatih kecerdasan emosinya sejak dini. Penelitian oleh Masum dan Khan (2014) mengatakan bahwa melakukan pendidikan tentang emosi sejak bangku sekolah mampu melatih seseorang agar dapat mengendalikan emosinya agar tidak terjadi agresivitas yang merugikan bagi orang tersebut dan sekitarnya, terlebih jika pendidikan tentang emosi dimasukkan ke dalam kurikulum sekolah agar dapat terfasilitasi dalam pelatihan emosi tersebut.

Penelitian oleh Alimoradi, Asadi, Asadbeigy, dan Asadniya (2014) juga mempunyai kesimpulan bahwa agresivitas yang sudah menjadi kebiasaan dapat direduksi dan dikurangi dengan kecerdasan emosi. Orang tua juga sangat berperan dalam membantu seseorang siswa atau individu dalam melatih emosinya sehingga mampu mengurangi kebiasaan-kebiasaan agresivitas siswa tersebut, peran dari orang tua adalah dalam hal mengontrol dan memberikan dukungan.

Berdasarkan data variabel kecerdasan emosi yang telah dilakukan di atas, diperoleh kategorisasi data penelitian yaitu subjek yang masuk pada kategori tinggi sejumlah 70 orang $(63,06 \%)$. Kategori sedang untuk subjek yang 
memiliki skor diantara 49 hingga 83 berjumlah 38 orang $(34,23 \%)$. Sedangkan subjek yang masuk dalam kategori rendah berjumlah 3 orang $(2,71 \%)$. Hal ini menunjukkan bahwa mayoritas subjek dalam penelitian ini masuk ke dalam kategori atlet yang memiliki tingkat kecerdasan emosi yang tinggi.

Berdasarkan kategorisasi data variabel agresivitas atlet yang telah dilakukan di atas, diperoleh kategorisasi data penelitian yaitu subjek yang termasuk dalam kategori tinggi berjumlah 8 orang $(7,21 \%)$. Kategori sedang dengan skor antara 60 sampai 90 berjumlah 35 orang (31,53\%). Sedangkan untuk kategori rendah yang memiliki skor dibawah 60 berjumlah 68 orang (61,26\%). Hasil kategorisasi skor agresivitas atlet yang didapatkan tersebut menunjukkan bahwa para atlet futsal memiliki tingkat agresivitas yang rendah.

Pada skala pengambilan data, untuk memperkuat profil subjek, peneliti memasukkan jumlah turnamen yang pernah diikuti untuk mengetahui seberapa banyak turnamen yang diikuti subjek. Berdasarkan data penelitian ini diketahui bahwa terdapat $12(10,81 \%)$ subjek yang telah mengikuti suatu turnamen sebanyak 1 sampai 3 kali. Kemudian terdapat 51 (45,95\%) subjek yang pernah mengikuti sebuah kejuaraan sebanyak 4 sampai 6 kali. Selanjutnya $35 \quad(31,53 \%)$ subjek diketahui pernah 7 sampai 10 kali mengikuti suatu kejuaraan, lalu terdapat $13(11,71 \%)$ subjek telah mengikuti turnamen sebanyak lebih dari 10 kali. Berdasarkan hal tersebut peneliti bisa mengambil kesimpulan bahwa mayoritas subjek pernah mengikuti lebih dari 4 kejuaraan yang berarti bahwa sudah berpengalaman dalam mengikuti suatu turnamen atau kejuaraan.
Terakhir, penelitian ini memiliki beberapa keterbatasan. Keterbatasan tersebut adalah alat ukur dalam penelitian ini tidak melewati professional judgement oleh dosen pembimbing skripsi untuk menentukan validitas isi. Kedua, masih ada beberapa faktor selain kecerdasan emosi dan memberi pengaruh pada agresivitas yang belum diteliti.

\section{Kesimpulan}

Berdasakan hasil penelitian yang telah diperoleh dapat disimpulkan bahwa terdapat hubungan negatif antara kecerdasan emosi dengan agresivitas pada atlet futsal. Hal tersebut berarti bahwa semakin tinggi kecerdasan emosi yang dimiliki oleh atlet maka akan semakin rendah agresivitasnya. Sebaliknya, semakin rendah kecerdasan emosi yang dimiliki oleh atlet maka semakin tinggi agresivitasnya. Kesimpulan lain dari penelitian ini ialah kecerdasan emosi yang dimiliki oleh atlet futsal mahasiswa termasuk dalam kategori sedang, sedangkan agresivitas subjek pada penelitian ini berada dalam kategori sedang pula.

\section{Saran}

Para atlet hendaknya dapat mengenali emosi dirinya sendiri, sehingga dapat mengantisipasi apabila emosi tersebut berpotensi mengganggu performa tim. Ketika para atlet futsal tidak mampu mengenali emosi diri, maka jangan ragu bercerita kepada pelatih guna membantu mengendalikan emosi, terutama saat bertanding, atau bisa juga mendatangi psikolog, dan yang paling utama bertukar pendapat sesama anggota tim futsal agar dapat saling menenangkan dan mengendalikan emosi di dalam lapangan 
sehingga tujuan utamanya tercapai yaitu juara.

Peneliti selanjutnya diharapkan melakukan uji coba kembali sebelum pengambilan data karena keterbatasan penelitian ini adalah tidak ada profesional judgement terhadap alat ukur dan menggunakan metode lain guna meneliti hubungan antara variabel kecerdasan emosi dengan agresivitas misalnya dengan metode eksperimen.

\section{Kepustakaan}

Alimoradi, M., Asadi, H., Asadbeigy, H., \& Asadniya, R. (2014). The effects of emotional intelligence on reduction of aggressive behaviors in juvenile with speech impairment. International Journal of Basic Sciences and Applied Research, 03, 265-269.

Baron, R. A., \& Byrne, D. (2005). Psikologi sosial jilid dua. Jakarta: Erlangga.

Buss, A. H. \& Perry. M. (1992). The aggression questionnaire. Journal of
Personality and Social Psychology, 61(3).

Das, P. P. P., \& Tripathy, S. (2015). Role of emotional intelligence on aggression: A comparison between adolescent boys and girls. Psychological and Behavioral Sciences, 1(4), 29-35.

Goleman, D. (1997). Kecerdasan emosional. Jakarta: PT. Gramedia Pustaka.

Gardner, H. (2006). Multiple intelligences: New Horizons. New York: Basic Book.

Masum, R., \& Khan, I. (2014). Examining the relationship between emotional intelligence and aggression among undergraduate students of Karachi. Educational Reasearch International, 3(3).

Mayer, J. D., Caruso, D. R., \& Salovey, P. (2016). The ability model of emotional intelligence: Principles and updates. Emotion Review. 8(4), 290-300, doi: 10.1177/ 175407391663 9667

Sears, D. O., Freedman, J. I. \& Peplau, L. A. (1994). Psikologi sosial. Jilid II. Jakarta: Erlangga. 